\title{
Strategies of Islamic Religious Education Teachers in the Development of Teaching Materials
}

\author{
*Aas Agustini ${ }^{1}$, Undang Ruslan W. ${ }^{2}$ \\ ${ }^{1,2}$ Universitas Singaperbangsa Karawang, Jl. HS.Ronggo Waluyo, West Java, Indonesia \\ *aasagustini108@gmail.com
}

\begin{abstract}
This research discusses Guru Pai's Strategy in The Development of Teaching Materials for Students at SDN Rengasdengklok Selatan 2. The type of research used is qualitative research. Research methods use interdisciplinary methods, including Management, pedagogical, sociological, and psychological methods. The primary data source of this study is the Teacher of Islamic Religious Education. Secondary data sources in this study are school profile data, theories on the concept of teaching materials development strategies, Master's Strategy Concepts in the Learning Process, and teaching materials development theory. Data collection using observations, interviews, and documentation. Data analysis uses the data reduction, data presentation, and withdrawal stages. Conclusion. The study results found that Islamic education learning strategies in the formation of Muslim personality students use two learning strategies, namely direct learning and indirect learning. Conclusions in the delivery of teaching materials in writing teaching materials to be more attractive, motivating, communicative, and help improve students' understanding of teaching and learning. Completeness of components, related to the package of teaching materials used as the main components, complementary components, and evaluation components of learning outcomes.
\end{abstract}

Penelitian ini membahas tentang Strategi Guru Pai dalam Pengembangan Bahan Ajar pada Siswa di SDN Rengasdengklok Selatan 2. Jenis penelitian yang digunakan adalah penelitian kualitatif. Metode penelitian menggunakan interdisipliner, antara lain Metode Manajemen, pedagogis, sosiologis, dan psikologis. Sumber data primer penelitian ini adalah guru Pendidikan Agama Islam. Sumber data sekunder dalam penelitian ini berupa data profil sekolah, teori tentang konsep strategi pengembangan bahan ajar, Konsep Strategi Guru dalam Proses Pembelajaran, dan teori pengembangan bahan ajar. pengumpulan data menggunakan observasi, wawancara, dan dokumentasi. Analisis data menggunakan tahap reduksi data, penyajian data, dan penarikan. Hasil penelitian menemukan bahwa strategi pembelajaran pendidikan agama Islam dalam pembentukan kepribadian muslim peserta didik menggunakan dua strategi pembelajaran, yaitu pembelajaran langsung dan pembelajaran tidak langsung. Kesimpulan penyampaian bahan ajar dalam penulisan bahan ajar menjadi lebih menarik, memotivasi, komunikatif, dan membantu meningkatkan pemahaman siswa terhadap pengajaran. Kelengkapan komponen, terkait dengan paket bahan 
ajar yang digunakan sebagai komponen utama, komponen pelengkap, dan komponen evaluasi hasil belajar

Keywords: PAI Teacher Strategy, Development, Teaching Materials.

Received: October 6, 2021; Revised: November 11, 2021; Accepted: December 23, 2021

\section{INTRODUCTION}

Education is the process of interaction between educators and learners (Istiq'faroh, 2020). As a process of education is the result of human engineering (Mahmud, 2017). In addition to being an engineering process, education is also a natural process in human life. Education is the same as life - a process of growth in human life that occurs without three engineerings. In essence, the educational results of human and natural engineering co-occur. It is impossible to process educational techniques without biological influences and otherwise natural education processes without human impact, at least human subjects.

Education is one of the activities in human life. Education in a systematic operational sense is the process of teaching and learning. Learning is the process of building knowledge, both natural and human. The construction process is done personally and socially. This process is active. Several factors, such as experience, knowledge, cognitive abilities, and the environment, affect learning outcomes (Zulida, 2017).

In this case, the teacher's role, which is a simple understanding, is the one who imparts knowledge to the students. In the view of the teacher community, people who do education in certain places, not necessarily informal educational institutions, but also in mosques, in surau / mussala, at home, and so on (Munirah, 2017).

Teachers do occupy an honourable position in society. The authority causes teachers to be respected so that the public does not doubt the teacher's figure. People are convinced that teachers can educate their children to be noble people. With the trust given by the community, it is on the shoulders of teachers who are given heavy duties and responsibilities. Carrying out the task is difficult, but it is even more difficult to assume responsibility. Since teacher responsibilities are limited to school walls and outside schools, teachers' training is in groups (classical) and individualized.

Teachers must realize that educating is preparing the next generation that will live in their future, not just the present. Therefore, in carrying out his duties, the teacher must have a strategy, i.e. outline the direction to act towards the goals determined. If associated with strategic learning, each activity is chosen to assist students in achieving learning goals.

According to the explanation of the Law of the Republic of Indonesia Number 20 of 2003, on the National Education System that Religious Education is intended to shape learners into people who believe and fear God Almighty and noble (UU Sisdiknas, 2003). During this time, the implementation of religious education has been widely criticized for emphasizing only cognitive aspects and ignoring the practical and cognitive-vocative elements, namely the willingness and determination to practice the values of spiritual teachings. As a result, there is a gap between knowledge and practice (Arifin, 2018). Therefore a teacher, in addition to providing knowledge, also guides his students to practice the teachings of Islam contained in that knowledge, 
because the practice of religious education is the ultimate goal of the success of the teaching and learning process, but in providing guidance must be in a good and wise way, so that children become better (Budiman \& Suparjo, 2021).

The subjects of Education and Curriculum of Islamic Religion Budi Pekerti 2013 consist of five aspects: Qur'an, Akidah, Morals, Jurisprudence, and History of Islamic Culture. The five elements of PAI have different characteristics (Zukhrufin, Anwar, \& Sidiq, 2021). The learning step with a scientific approach is still a problem for Islamic Religious Education, and Budi Pekerti is in the observation stage. In the observation step, learners should be treated to fact-based learning materials (empirically beatable) or phenomena that can be explained by certain logic or reasoning. It's not just about fantasy, legend, or fairy tales. This becomes a solution because the Aqidah aspect contains a charge of martyrdom that is difficult to present facts that c can prove empirically. For example, when discussing belief in the Angel Izroil as an angel tasked with taking lives. The question that then arises is, "How does the teacher give the facts about the angel of Izrail that can be harmed or presented empirically?" (Soleha, 2019).

The observation step is an empirical activity involving the role of the senses so that the observer can photograph objects holistically (Nurmaidah, 2014). Since the observed object consists of the reasons, it must be a physical-material object. This is a contentious question in PAI. The object of study in PAI is not only a physical-material object, but PAI also examines metaphysical entities, that is, things related to the invisible realm, such as angels (Wafi, 2017). In addition, PAI even examines eschatological aspects, such as cemeteries, the afterlife, heaven, and hell. The field of metaphysical-eschatological studies became the subject of Aqedah Akhlaq.

Teachers who use teaching material development strategies must adapt to the conditions and atmosphere of the classroom. Of course, teachers are asked to play more roles using varied learning strategies. Every learning strategy has its advantages and disadvantages. In order not to have boring learning activities for learners, a teacher needs to create a good learning strategy and be in harmony with the needs of learners (Ikhwan, Farid, Rohmad, \& Syam, 2020).

Based on this phenomenon, the author considers it necessary to research pai teacher strategies to guide the practice of teaching materials to produce reliable output, especially in creating intelligent and Islamic learners. Some previous studies have not found a reliable system in teaching. This research is fundamental to choosing the right strategy in education. Likewise, researchers will specifically review PAI's Master's Strategy in Teaching Materials Development in Students at SDN Rengasdengklok Selatan 2.

\section{Concept of Teacher Strategy in the Learning Process}

It initially used the term strategy in the military world, which. It means using all military power to win the war. A person who plays a role in establishing a strategy to win the battle before taking action will consider how the strength of the troops he has both in terms of quantity and quality; for example, the ability of each person, the number and power of weaponry, the motivation of his troops and so on (Bahtiar, 2017).

According to J.R. David, in the world of education, strategy is interpreted as "a plan, method, or set of activities designed to achieve a specific educational goal" (Zulkifli, 2018). Thus a learning strategy can be interpreted as a plan that contains a series of 
activities designed to achieve specific educational goals. According to Darsono, learning can be divided into two, namely in general and specifically. Understanding learning, in general, is an activity carried out by educators so that the behaviour of learners changes in a better direction. While learning is an activity that is done unconsciously and unintentionally. Learning must therefore have a learning purpose, a process of relatively constant behaviour change that occurs due to experience or practice (Pohan, 2018).

Learning teaches learners using educational principles and learning theories, the main determinants of academic success. Learning is a two-way communication process. Teaching is done by teachers as educators, while learners or students learn. Learning is the process by which a person's environment is deliberately managed to participate in certain behaviours under particular conditions or generate responses to certain situations. Learning is a specific part of education (Mursyidi, 2020). Learning is the actualization of a curriculum that requires teachers to create and grow learners' activities following the program plan (Nurmaidah, 2014).

Based on several definitions of learning, one can understand that learning is a deliberate process designed to create learning activities in individuals. In other words, learning is external and deliberately designed to support the internal learning process in individuals.

The ability to explain that strategies guide teaching materials practice are learning activities that teachers and learners must undertake to achieve learning goals effectively and efficiently. In line with the above opinion, Dick and Carey also mentioned that learning strategies are a set of learning materials and procedures used together to cause learning outcomes in learners.

\section{Development of Teaching Materials}

With deep teaching materials of different types and forms, the teacher's teaching time will be shortened. This Means the teacher gets students to study the previous material primarily to teach and asks them to answer questions in the last part of each primary language. Thus, the arrival in the teacher's classroom no longer needs to explain all the subject matter to be discussed but only discusses material that the student does not know. Thus, teaching time can be more saved, and the rest of the time is used to discuss, ask for answers, or do other learning activities. Change the role of the teacher from teacher to facilitator.

With teaching materials, the learning process runs more effectively because the teacher serves as a teacher and a facilitator who can guide students to understand one learning material in depth. For example, with the time he has, the teacher not only teaches but also performs other activities, for example, carrying out asking for answers with students or between students about basic things that students still have not controlled, asking students to have in-depth group discussions solving problems related to the topic discussed, asking students to report the results of their observations about something that is still not discussed, And others. In such a way, there will be active interaction between The Teacher and the student. This in-depth teacher serves more as a facilitator in Managing all of the activities mentioned above.

Improve the learning process to be more effective and interactive. Teachers will have more free time to manage the learning process to run more effectively and efficiently with teaching materials. In addition, the chosen learning method is not only a one-way 
lecture method, where the teacher is considered the only source of information but is more interactive with various techniques that can be chosen by the teacher, such as discussion methods, simulations, and role-playing. This way, he can complete the subject matter on time because the teacher no longer must spend his sermon, but he only needs to discuss certain things that the student has not mastered.

Students can learn without having to be teachers or friends of other students. With teaching materials designed and written in an excellent and logical order and line with the existing lesson schedule in one semester, students can learn teaching materials independently wherever they like. Thus, students are better prepared to take lessons because they already know the material to be discussed first. In addition, by studying teaching materials first, at least students already know the core concepts of the material discussed in the meeting. He can identify material that is still unclear, to be asked later by the teacher in the class. In addition, with the teaching materials that have been learned, students will be able to anticipate what tasks their teacher will give after the lesson is completed. Thus, students are better equipped to perform tasks. Students can study anytime and anywhere they want, with students allowed to determine when and where they want to study, not just look in the classroom. Imagine if students were not given teaching materials. What can they read and learn at home or elsewhere? Without sharing teaching materials with students, students will rely heavily on you to gain knowledge and skills. Students' free time outside of school activities will be wasted if not filled by positive actions. In this case, teaching materials are an alternative to reading materials, learning materials, and discussion materials outside of formal school activities. Students can learn at their own pace. That is, students can determine their way and speed in learning. As we know, a person's rate in learning something is very diverse. Some students learn fast, some moderate, and others are also learning slowly, even very slowly. Through teaching materials, the diversity of students' learning speed can be accommodated and overcome.

\section{METHOD}

Because it is done scientifically, this form of research is qualitative or neutralistic. This qualitative study aims to determine the pai teacher method to train students in SDN Rengasdengklok Selatan 2 in the practice of teaching materials. The study takes an interdisciplinary approach that includes management, pedagogical, sociological, and psychological elements. The study utilizes two different types of data sources: Primary data is the leading data collected directly from informants, in this case, PAI teachers, in field studies (Ikhwan, 2021). This data is collected through interviews (interviews) and secondary data (existing documents and relevant study results found by academics). This information comes in the form of important documents relating to school profiles, theories about learning methodologies, Islamic religious education, and the development of teaching materials. Researchers are present at the research site to conduct research and collect factual data relevant to this topic. A researcher's data collection method is observation or observation by studying and recording behaviour closely by directly observing or observing an individual or group (Gunawan, 2013);(Moleong, 2019);(Nugrahani \& Hum, 2014);(Strauss \& Corbin, 2003). Many phases and steps must be emphasized to perform this qualitative data analysis, including word reduction, data display, and verification. 


\section{RESULT AND DISCUSSION}

Teaching Materials Development Procedures in the learning process type and role of teaching materials in general learning. The development of teaching materials needs to be done systematically based on interrelated steps to produce quality teaching materials. During this time, teachers are less trained to develop their teaching materials because they often use ready teaching materials in the elementary school or high school learning process. Use is available in the market. The results of this discussion will be focused on teaching materials development procedures, hoping that PAI teachers can develop their teaching materials in the future. Using the teaching materials he developed, teachers will be more confident in carrying out learning activities so that the transformation of science and technology becomes a responsibility. Answers in class can be done effectively and efficiently. If the learning activities have been going well, it is expected that the student's learning results will also be good. Back to the teaching materials development procedure, you need to do at least five main steps, namely as follows.

\section{Teaching Material Development Procedure}

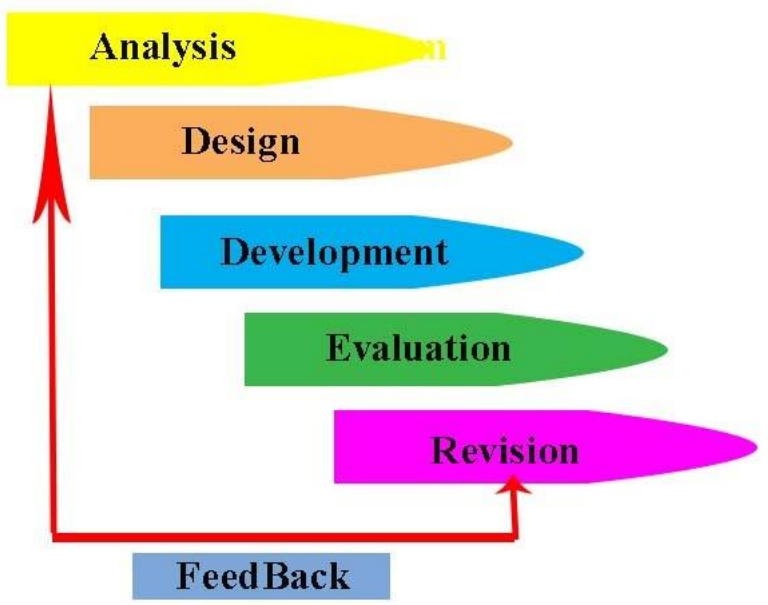

Figure 1. Teaching Materials Development Procedures

\section{Analysis}

At this stage, all you need to do is identify the initial behaviour of the student. This relates to their level of mastery and ability in the field of science or the subject to be awarded. How far do students master the contents of our issues? In addition, it also recognizes the initial characteristics. It deals with the features and demographic data of students, including origin, age, language used, family economic background, and so on. This information regarding the student's initial behaviour and early characteristics will be of great benefit to you when you determine the type of teaching material to be developed. In addition, the information will also lead you to the selection of teaching material delivery strategies. For example, suppose your students are mostly farm children who live in rural and mountainous areas. In that case, the examples given in teaching materials relating to exposure to the subject matter should suit their living situation and conditions. If the model is not contextual, it will be difficult for students to digest exposure to the material in your teaching materials. An excellent introduction to the student's initial behaviour and early characteristics is indispensable to 
determining the student's needs, then designing teaching materials that benefit the student.

\section{Design}

Once the information about the student's initial behaviour and characteristics is known, you are ready to advance to the next step in the development of teaching materials, namely the design stage. At this design stage, you are required to undertake the formulation of learning objectives, the result of a concept map of subjects, and the development of the outline of the learning program.

Based on the analysis that has been done, a map or diagram will be obtained about the competencies to be achieved by students, both general competence and unique competencies. If reformulated with applicable rules, broad competencies and specific competencies will be the general learning objective and the particular learning objective as for the laws that apply, among other things. Complement the objective components of learning, namely audience, behaviour, conditions, degrees. Audience $=$ Who will use your teaching materials? For example, a 6th grader.

Behaviour, what kind of learning outcome behaviour requires competence. The behaviour of these learning outcomes must be observable and measured. For example, it could correctly show Mount Slamet on a blind map.

Conditions, facilities and infrastructure needed to measure the achievement of competence. For example, if the competencies requested by students can indicate the location of Mount Slamet in the map, then a blind map as a condition must be available. Degree $=$ What level of competency achievement suggests a student's success? For example, correctly and $100 \%$ correct.

Learning objectives show what students must do to learn well successfully or what competencies students will achieve after going through the process. Learn. Thus,

you are expected to write down the purpose of learning to use active verbs and avoid unclear verbs, such as understanding, knowing, mastering them. Knowing, realizing, and experiencing.

Learning goals are essential for you to formulate well before developing teaching materials. Good learning objectives will guide you in choosing learning topics, strategizing learning, choosing learning media and methods, and developing learning outcome evaluation tools.

The learning activities are closely related to the learning objectives, and the lesson's topic (material) delivered. Wardani states that if the material presented is new, it is natural that learning activities begin with the presentation of information (Wardhani \& Wihardit, 2011). As explained in the presentation sequence and the sequence of learning, the production of data can be done in various ways, not necessarily in the form of descriptive text that must be done.

Students read but can also take the form of games, model shows, video playback, and various other conditions. Meanwhile, suppose the material given to students is an advanced material that has been discussed before. In that case, the deepening of the material in group discussions using LKS (student worksheets) will be more appropriate. The primary purpose of this advanced activity is to strengthen the student's ability in material mastery. 
The following table can help you design learning activities based on the materials presented.

Table 1. Relationship of Activity Variety with Material Nature

\begin{tabular}{|c|c|c|c|}
\hline \multirow[b]{2}{*}{ No. } & \multirow[b]{2}{*}{ Material Nature } & \multicolumn{2}{|c|}{ Variety of Activities } \\
\hline & & $\begin{array}{l}\text { Presentation of } \\
\text { Information }\end{array}$ & Activity \\
\hline 1 & Informative & Narrative, descriptive & $\begin{array}{l}\text { Group discussion (LKS) Q\&A } \\
\text { (in text question), read tables, } \\
\text { diagrams, maps, drawings, } \\
\text { And others. }\end{array}$ \\
\hline 2 & $\begin{array}{l}\text { Conceptual (theory, } \\
\text { proposition, principle, } \\
\text { etc) }\end{array}$ & Deductive or inductive & $\begin{array}{l}\text { Group discussion (LKS), sample } \\
\text { group discussion (LKS) written } \\
\text { examples, sample images, } \\
\text { examples of videos, simulations }\end{array}$ \\
\hline 3 & Procedural & $\begin{array}{l}\text { Descriptive } \\
\text { explanatory }\end{array}$ & $\begin{array}{l}\text { Exercises, shows, video } \\
\text { examples, } \\
\text { simulation, practice (LKS) }\end{array}$ \\
\hline 4 & Skills & $\begin{array}{l}\text { Descriptive } \\
\text { explanatory } \\
\text { (modeling) }\end{array}$ & $\begin{array}{l}\text { Shows, rehearsals, video } \\
\text { examples, } \\
\text { simulation, practice (LKS) }\end{array}$ \\
\hline 5 & Values/attitudes & $\begin{array}{l}\text { Argumentative } \\
\text { descriptive }\end{array}$ & $\begin{array}{l}\text { Shows, video examples, } \\
\text { simulations, } \\
\text { Practice (LKS) }\end{array}$ \\
\hline
\end{tabular}

(Adapted from Wardani, Relation to Material Nature and Presentation Activities)

\section{Development}

To make effective teaching materials, careful planning and design are needed. Here are some ideas to help you start making teaching materials: Write down whatever you can, whether in worksheet form or as part of a book preparation or practice guide. I don't believe teaching materials should be written in a particular order. For known participants, write or develop educational materials. Participants must be able to learn from the teaching materials made. Acquiring interesting, helpful, and successful teaching materials for participants requires a variety of media, teaching resources, activities, and feedback. The manufacture of teaching materials also involves using various examples, props, drawings, and packaging. To understand the instructor's goals, the writing style for textual, narrative, explanatory, descriptive, argumentative, and command parts is essential.

\section{Evaluation and Revision}

The process of obtaining a varied reaction from various parties to the resulting teaching material is known as evaluation. This answer should be seen as feedback on improving and improving the quality of educational materials. To determine the success of the educational materials developed, evaluation is critical. Is the prepared educational material understandable, well-read, and teach participants? Furthermore, evaluation is needed to improve the teaching material and make it good. There are many areas for reviewing educational materials in general, including expert reviews (more emphasis on scientific validity and accuracy of coverage). One-on-one trial (One participant reviews teaching materials and then comments on readability, language, illustration, expression, and difficulty level). Problems with a small number of people (One small group examines teaching materials, is then asked to comment on 
readability, language, illustration, expression, and difficulty level) Field tests (to see if the teaching material can achieve the goal.) Whether teaching materials are considered acceptable, and so on.

\section{CONCLUSION}

A teacher is expected to develop teaching materials for use in the learning process in his class. In the process of developing teaching materials, seven factors must be considered by teachers for teaching materials to be effective. These factors are as follows. Accuracy of content relating to content validity and content alignment.

The accuracy of coverage, relating to the breadth and depth of the material and the wholeness of the concepts discussed based on their field of knowledge.

Digesting teaching materials related to the ease of teaching materials is understood by students as users. The use of language relates to the selection of language varieties, word selection, effective use of sentences, and meaningful paragraphs. Argument/packaging, relating to the layout of information in a single printed page.

Illustration, related to the variety of message delivery in the writing of teaching materials, is more attractive, motivating, communicative, and help improve students' understanding of the content of the message. Completeness of components, related to the package of teaching materials that serve as the main components, complementary components, and evaluation components of learning outcomes.

\section{REFERENCES}

[1] Arifin, S. (2018). Pendidikan Agama Islam. Deepublish.

[2] Bahtiar, A. R. (2017). PRINSIP-PRINSIP DAN MODEL PEMBELAJARAN PENDIDIKAN AGAMA ISLAM. TARBAWI: Jurnal Pendidikan Agama Islam, 1(2). https://doi.org/10.26618/jtw.v1i2.368

[3] Budiman, S., \& Suparjo, S. (2021). Manajemen Strategik Pendidikan Islam. JISIP (Jurnal Ilmu Sosial Dan Pendidikan), 5(3).

[4] Gunawan, I. (2013). Metode penelitian kualitatif. Jakarta: Bumi Aksara, 143.

[5] Ikhwan, A. (2021). Metode Penelitian Dasar (Mengenal Model Penelitian dan Sistematikanya). Tulungagung: STAI Muhammadiyah Tulungagung.

[6] Ikhwan, A., Farid, M., Rohmad, A., \& Syam, A. R. (2020). Revitalization of Islamic Education Teachers in the Development of Student Personality. 1st Borobudur International Symposium on Humanities, Economics and Social Sciences (BIS-HESS 2019), 162-165.

[7] Istiq'faroh, N. (2020). Arti Pendidikan. Lintang Songo : Jurnal Pendidikan, 3(2).

[8] Mahmud. (2017). Psikologi Pendidikan. Bandung: Pustaka Setia.

[9] Moleong, L. J. (2019). Metodologi Penelitian Kualitatif (Edisi Revisi). PT. Remaja Rosda Karya. https://doi.org/10.1016/j.carbpol.2013.02.055

[10] Munirah. (2017). Akhlak Dalam Perspektif Pendidikan Islam. Jurnal Pendidikan 
Dasar Islam, 4(2).

[11] Mursyidi, W. (2020). Kajian Teori Belajar Behaviorisme Dan Desain Instruksional. Almarhalah| Jurnal Pendidikan Islam, 3(1). https://doi.org/10.38153/alm.v3i1.30

[12] Nugrahani, F., \& Hum, M. (2014). Metode penelitian kualitatif. Solo: Cakra Books.

[13] Nurmaidah. (2014). Kurikulum Pendidikan Agama Islam. MA Jurnal Al-Afkar, $3(2), 41-54$.

[14] Pohan, S. (2018). Manajemen Sekolah: Wujudkan Guru Profesional. Tarbawi : Jurnal Ilmu Pendidikan, 14(2). https://doi.org/10.32939/tarbawi.v14i2.265

[15] Soleha. (2019). Pengembangan Kurikulum Pendidikan Agama Dalam Menciptakan Sikap Toleransi Beragama di Madrasah Aliyah dan Sekolah Menengah Atas Kabupaten Bangka. Scientia: Jurnal Hasil Penelitian, 4(2). https://doi.org/10.32923/sci.v4i2.1132

[16] Strauss, A., \& Corbin, J. (2003). Penelitian Kualitatif. Yogyakarta: Pustaka Pelajar.

[17] UU Sisdiknas, N. 20. (2003). Undang-Undang Sistem Pendidikan Nasional. Records Management Journal, 1(2).

[18] Wafi, A. (2017). Konsep Dasar Kurikulum Pendidikan Agama Islam. Edureligia; Jurnal Pendidikan Agama Islam, 1(2), 133-139. https://doi.org/10.33650/edureligia.v1i2.741

[19] Wardhani, I., \& Wihardit, K. (2011). Penelitian Tindakan Kelas. Tangerang: Universitas Terbuka.

[20]Zukhrufin, F. K., Anwar, S., \& Sidiq, U. (2021). Desain Pembelajaran Akhlak Melalui Mata Pelajaran Pendidikan Agama Islam. JIE: Journal of Islamic Edication, 6(2), 17-35.

[21]Zulida. (2017). Konsep Pendidikan Akhlak Dalam Islam. Dewantara, III.

[22]Zulkifli. (2018). REGULASI PENDIDIKAN ISLAM. Rausyan Fikr: Jurnal Pemikiran Dan Pencerahan, 14(02). https://doi.org/10.31000/rf.v14i02.904 